\title{
The Historian (of Religions) as Detective
}

\author{
Luther H. Martin
}

University of Vermont

\begin{abstract}
Since my graduate school days, I have been interested in the philosophy of history, especially in historiographical methods. And, I have long been intrigued by the proposition that such methods are also represented by those of detectives (e.g., Robin Winks 1969), particularly, the detectives of fiction. However, it was only with my retirement that I began extensively to read detective novels and, given my historical field of GraecoRoman religions, I was especially interested in those of Lindsey Davis about Marcus Didius Falco, a "private informer," that are set in the first-century Roman Empire. What might be the historiographical value of such novels, if any? This question was intensified by the recent argument of philosopher Alex Rosenberg (2018) that historical narratives are no more trustworthy than fiction. Consequently, I reflect, in this article, on the historical value both of historical narratives and of historical fiction.
\end{abstract}

\section{Keywords}

detectives, historical-detective stories, historiography, historical narratives, Lindsey Davis, literary stories, Theory of Mind, Alex Rosenberg, Lisa Zunshine.

\section{Contact address}

Luther H. Martin, Professor Emeritus, University of Vermont, 161 St. Paul Street, \#304; Burlington, VT (USA) 05401; e-mail address: luther.martin@uvm.edu 


\section{A detective either follows a chain of evidence to the suspect, or the detective begins with the suspect and, in retrograde fashion, follows the evidence back to the crime.}

\section{Introduction}

With my retirement from university teaching, I began to have more time to devote to my interest in reading fiction. A senior colleague and friend from the Department of English, whose views on what constitutes "good literature" I respect, once remarked that, in his spare time, he enjoyed reading detective novels. Apart from the Sherlock Holmes stories, I was relatively unfamiliar with this genre, so I asked him for some recommendations, and I, too, became attracted to reading detective novels. ${ }^{1}$

Apart from being simply an entertaining pastime for an elderly gentleman with time on his hands, I began to note a number of more interesting and insightful characteristics of this type of literature. First of all, many of these are really quite well written, one American writer of detective novels even being compared to William Faulkner. ${ }^{2}$ Secondly, the attention to details characteristic of these novels offers a virtual travelogue of their settings as well as exacting insight into local socio-cultural life. ${ }^{3}$ Thirdly, like many Verdi operas that were censored because they challenged reigning autocratic and imperious views, ${ }^{4}$ a number of detective novels, especially those set in Italy, provide "cover" for criticisms of bureaucratic corruption, corporate avarice, underworld influences, ${ }^{5}$ and socio-economic

\footnotetext{
${ }^{1}$ Interestingly (coincidentally?), a number of fictional detectives, having reached a "certain age," are also portrayed as facing issues of aging and their own retirements, from Sherlock Holmes ("The Adventure of the Lion's Mane," 1926) to more contemporary investigators, such as James Lee Burke's Dave Robicheaux, Ian Rankin's John Rebus, or Michael Connelly's Harry Bosch (Alexandra Alter. "The [Really] Long Goodbye: He's Got a Gun, a Badge_ and Rheumatoid Arthritis; The Iconic Detectives of Best-selling Authors from Michael Connelly to Ruth Rendell are Fighting a New Foe: Old Age.” Wall Street Journal (Eastern edn.). July 1, [2011]: D.1.). Of course, these investigators inevitably return to detection as investigative consultants (e.g., Holmes), by volunteering their expertise to interested police departments (e.g., Bosch), or by accepting part-time or temporary employment in those departments (e.g., Robicheaux)—otherwise, the succession of novels would end (as is the case, e.g., with the Rebus series).

2 Wirt Williams, Review of James Lee Burke's Half of Paradise, “On the Tracks to Doom: HALF OF PARADISE," (Boston: Houghton Mifflin, 1965), New York Times Book Review, 14 March (1965), BR46.

${ }^{3}$ E.g., the Cajun country of southern Louisiana in the Dave Robicheaux series by Burke, Venice in the Inspector Guido Brunetti series by Donna Leon, Florence in the Marshal Guarnaccia series by Magdalen Nabb, Barcelona in the Pepe Carvalho novels by Manuel Vázquez Montalbán, Edinburgh in the Inspector Rebus series by Rankin, of course, the mean streets of Los Angeles in the Philip Marlowe series by Raymond Chandler, and even the ancient Roman Empire in the Falco series by Lindsey Davis.

${ }^{4}$ E.g., Un Ballo in Maschera, Rigoletto.

${ }^{5}$ E.g., Rankin in Edinburgh; Montalbán in Spain; Leon, Nabb, and Davis, in Italy, Andrea Camilleri (in his Inspector Montalbano series) in Sicily; Dennis Lahane in Boston (e,g., Mystic River, 2001; The Given Day, 2008).
} 
class differences. ${ }^{6}$ And, detective novels provide the means for their authors to explore the various motivations of their suspects for violence, especially, the individual and the collective nature of what they forthrightly call the "evil that men do."

Most significant for me, however, is that the "investigations of the detective" have been compared to historiographical methods. ${ }^{7}$ For, despite my having employed various methodologies in my work, I have always considered myself to be primarily a historian. ${ }^{8}$ The main affinity I find with detective novels, therefore, is this correspondence of historiographical methods with criminal investigation —especially as those investigations are portrayed in detective novels. In the view of Edgar Allen Poe, considered the architect of the modern detective novel, " the primary plots of such stories— he referred to his as "tales of ratiocination" 10 - are concerned with "ascertaining truth" through "intuitive logic, astute observation, and perspicacious inference" ${ }^{11}$ - a process of detection that is, of course, analogous to historiographical method generally. ${ }^{12}$

\section{The Fictive Detective as Historian}

The Vermont poet Mary Jane Dickerson has written about a "convergence of history and poetry" in which she contends that history often emerges in poems in ways that it might not otherwise emerge. ${ }^{13}$ "Early oral poetry," she reminds us, "often served the special function of recording a people's history even before written language."14 While Dickerson's examples of historico-literary convergence are drawn from American poetry, it might be argued that singular aspects of history might be preserved and expressed in literature generally, ${ }^{15}$

\footnotetext{
${ }^{6}$ E.g., between Northern and Southern Italians, especially between Sicilians and Calabrians (Nabb) or between Edinburgh and Glasgow (Rankin).

${ }^{7}$ Robin W. Winks, The Historian as Detective: Essays on Evidence, (New York: Harper \& Row, 1969).

${ }^{8}$ Panayotis Pachis and Donald Wiebe, "Preface," in Chasing Down Religion: In the Sights of History and the Cognitive Sciences. Essays in Honor of Luther H. Martin, ed. P. Pachis and D. Wiebe, (Thessaloniki: Barbounakis Publications, 2010), XLVIII; rpt. (Equinox, Sheffield, UK, 2010), XXXVII.

${ }^{9}$ With the publication of his The Murders of the Rue Morgue in 1841.

${ }^{10}$ Kenneth Silverman, Edgar A. Poe: Mournful and Never-ending Remembrance, (New York: Harper Perennial, 1991), 171-174; Carole Kismaric and Marvin Heiferman, The Mysterious Case of Nancy Drew \& The Hardy Boys, (New York: Simon \& Schuster, 1998), 56-57.

11 “Edgar Allan Poe," New World Encyclopedia: http://www.newworldencyclopedia.org/entry/Edgar_Allan_Poe (accessed 5/2/2019), see also: https://en.wikipedia.org/wiki/Detective_fiction (accessed, 5/2/2019), and https:// goldenageofmystery.com/authors-page-1\%3A (accessed, 5/2/2019).

${ }_{12}$ Carl L Becker, "Everyman His Own Historian,” American Historical Review 37 (1932), 221-236; rpt. in Winks, The Historian as Detective: Essays on Evidence, 5-23.

${ }^{13}$ Mary Jane Dickerson, "The Convergence of History and Poetry: Part I-Toward a Poetics of the Past," in Vermont Poets and Their Craft, ed. Neil Sheppart and Tamra J. Higgens, (Brattleboro, Vermont: Green Writer's Press, 2019), 83-92.

${ }^{14}$ Dickerson, The Convergence of History and Poetry, 83.

${ }^{15}$ Luther H. Martin, "Consilience: Science, the Humanities, and the Study of Religion," Culture and Research, forthcoming article.
} 
particularly in historical novels. As a historian of Graeco-Roman antiquity, I have been especially intrigued by the historical-detective novels of British author Lindsey Davis, first recommended to me by an internationally-renowned and quite reputable classicist. Davis' historically accurate but imaginatively enlivened accounts of everyday life in the first-century Roman Empire offer a striking example of the historico-literary convergence about which Dickerson writes.

Davis' novels feature the adventures of Marcus Didius Falco, a Roman delator or private 'informer' that is, for all practical purposes, equivalent to the modern private detective. Under the empire, delatores were considered to be disreputable, like the modern detective, as somewhat "seedy." Nevertheless, delatores were sometimes employed in imperial service (as is Falco by Vespasian) to preserve the interests, public and personal, of the Emperor. ${ }^{16}$ His service was not only rewarded financially but, eventually, with an elevation in social status.

Falco's 'delations' take him throughout the urban cityscape of Rome where he lives, much of which remains identifiable today. And, his investigations as an imperial agent take him to remote parts of the Empire to gather intelligence in the provinces or to check on corruption in the peripheral bureaucracy. Davis meticulously describes Falco's journeys to such places as Roman Britannia, or to Germania Inferior, or to the Decapolis in the provinces of Syria and Arabia Petraea-and their landscapes. These imaginary peregrinations are the occasions for Davis to describe accurately what is known of everyday life in Rome and in its provinces, or to imaginatively recreate details of everyday life that might be plausibly inferred from the historical record. For example, Davis' description of Falco's mission to Germania as a special envoy of Vespasian, set in the context of the Batavian revolt against Rome led by Gaius Julius Civilis in $69-70 \mathrm{AD},{ }^{17}$ is an extended riff on Tacitus' vivid account of this rebellion in Book IV of his Histories.

Davis forthrightly concedes that the Falco series is fiction. ${ }^{18}$ Nevertheless, she strives for historical accuracy, ${ }^{19}$ and historically and archaeologically accurate information enriches her narratives as she explores such themes as Roman friendships and family relationships, the strictly defined social roles and rule among Roman citizens, the interactions between citizens, provincials, and non-citizen inhabitants of the Empire, and the economic corruption and political intrigue that typified all of these relationships. And she describes with elegant asides such particulars as the local flora and agricultural practices, modes of dress and culinary habits, the architecture and interior furnishings of Roman insulae and villas, etc., etc.

\footnotetext{
${ }^{16}$ Davis' portrayal of delatores under the Emperorship of Vespasian is historically accurate (Steven H. Rutledge, Imperial Inquisitions: Prosecutors and Informants from Tiberius to Domitian, (London: Routledge, 2001), if that of Falco is exaggerated for comedic effect.

${ }^{17}$ Lindsey Davis, The Iron Hand of Mars, (London: Hutchinson, 1992).

${ }^{18}$ Davis, "Authors' Introduction," in The Silver Pigs [1989], (New York: Minotaur Books 2011), xvii; and Davis, Falco on the Loose [Three of Davis' novels bound as one: Last Act in Palmyra (1994), Time to Depart (1995), A Dying Light in Corduba (1996)], (London: Arrow Books, 2001a), 1205.

${ }^{19}$ Davis, "Introduction," in Falco on the Loose, xvii.
} 
While there are allusions to religious practices under the Roman Empire throughout the Falco novels, Roman state religion is the explicit background for the eleventh of the Falco novels, One Virgin Too Many, ${ }^{20}$ and, consequently, is of special interest to historians of Roman religions. In this novel, for example, the Emperor appoints Falco to the position of "Procurator of the Sacred Geese and Chickens of the Senate and People of Rome" at the Capitoline temple of Juno Moneta. Although this appointment is employed for comic effect—one of Falco's responsibilities is picking up the poultry's droppings—a "keeper of the sacred chickens" (pullarius) is actually documented for a certain Atimetus, freedman dedicator of a memorial funerary relief for the centurion Marcus Pompeius Asper, prefect of the XX Legion in Britain; ${ }^{21}$ the memorial itself depicts a chicken pen. ${ }^{22} \mathrm{~A}$ roost of augural chickens were maintained by priests in ancient Rome and habitually consulted on matters of political and military importance. ${ }^{23}$ Geese were sacred to Juno Moneta and were raised by priests at her temple on the Capitoline. ${ }^{24}$

And it is in this novel that Vespasian elevates Falco from plebian to equestrian status as a reward for his service to the Emperor. Equestrian status was the second of the propertybased classes of ancient Rome, ranking just below the senatorial class (to which Helena, his wife/partner belongs). ${ }^{25}$

In One Virgin Too Many, Falco investigates a murder that occurred during a festival of the Arval Brethern in addition to looking into the disappearance of a young girl who is expected to be one of the next Vestal Virgins. His new social status as an equestrian together with his appointment as a procurator in state religion, allows him access to the various religious cults that constituted the official Roman religious system. Falco's inside access to official Roman religions permits Davis to explore what is known of the collegium Fratres Arvales, of the Vestal Virgins (sacerdos Vestalis), and of the flamines maiores, especially the office of the Flamen Dialis, the Priest of Jupiter, who is "as close to the gods as you could

${ }^{20}$ Davis, One Virgin Too Many, (New York: Mysterious Press, 1999).

${ }^{21}$ In addition to prefect of Legio XX Victrix, the relief also commemorates Marcus Pompeius Asper as a centurion in Legio XV Apollinaris, a centurion of the Praetorian Guard, and primus pilus of Legio III Cyrenaica (Maureen Carroll, Spirits of the Dead: Roman Funerary Commemoration in Western Europe, (Oxford: Oxford University Press, 2006), 143.

22 https://twitter.com/OptimoPrincipi/status/844658972628004869 (accessed 5/15/2019). The memorial is currently in the Palazzo Albani (del Drago), Rome.

${ }^{23}$ E.g., Cicero, De Natura Deorum II.3; Livy, Ab Urbe Condita 10.40; Valerius Maximus, Factorum ac dictorum memorabilium libri IX 1.4.2; 1.4.3; 8.1.abs.4; 1.6.7; Suetonius, Tiberius 2.2.

${ }^{24}$ Dionysus Halicarnassensis, Antiquitates Romanae 137.3; Ovid, Fasti 1. 454; Plutarch, Vita Camillus 27. 1-3. See also Jeremy Mynott, Birds in the Ancient World, (Oxford: Oxford University Press, 2018).

25 There were three types of marriage (matrimonium) under Roman law (Karen K. Hersch, The Roman Wedding: Ritual and Meaning, (Cambridge: Cambridge University Press.2010: 20-27): confarreatio, a highly formal and ritualized ceremony limited to patricians, coemptio, marriage by a husband's fictive purchase of a wife from her father, and, usus, which was essentially marriage by common law, recognized when two people lived together for a year (Gauis' second century Institutiones iustiniani 1.111). Usus was the relationship between Falco and Helena. Since Falco was a pleb, his marriage to Helena, who was a senator's daughter, violated Roman social protocol and was considered scandalous. This disreputable situation was ameliorated (somewhat) when Falco achieved equestrian status. 
get in human form." ${ }^{26}$ Mentioned in passing in the course of Falco's investigations are Minerva (the third of the Capitoline Triad with Jupiter and Juno), the College of Augurs, the Sodalis Augustalis (the cult of the deified Augustus), the festivals of Juno Moneta, Bona Dea, Bellona, Hercules, Dea Dia (Ops), as well as the household protectors and bringers of good fortune, the Lars and Penates.

Since the rituals of the official Roman state religions must be precisely performed, ${ }^{27}$ Falco correctly concludes that they are all but appeasements "to gods by the mindless repetition of meaningless words and actions." ${ }^{28}$ And, since the priests in all of these official cults and colleges were chosen only from persons of distinction among Roman citizens, our detective again concludes rightly that "[ $\mathrm{t}]$ he fanciful rites of the[se] ancient cults, where only the favored may communicate with the gods, are about power in the state." ${ }^{29}$ This relationship between religion and the state increased with the identification of the Pontifex Maximus with Augustus and, subsequently, with successive Emperors. ${ }^{30}$

Davis' attention to historically accurate details of everyday life in familiar and foreign places of the Roman Empire provides a richly textured background for her characters' adventures - and historical instruction for the modern reader-as well as representing the modus operandi of fictional detectives, past and present. ${ }^{31}$

\section{The Historian as Detective}

The reasoning processes of the historian has been compared to that of a detective at least since the philosopher of history Robin G. Collingwood concluded, in his influential The Idea of History (1946), that, "The hero of a detective novel is thinking exactly like an historian when, from indications of the most varied kinds, he constructs an imaginary

\footnotetext{
${ }^{26}$ Davis, One Virgin Too Many, 176.

${ }_{27}$ Pliny, Naturalis historia 20. 10-11; see Fritz. Graf, "ritual," in The Oxford Classical Dictionary, 4th ed., eds. Simon Hornblower, Anthony Spawforth and Esther Eidenow, (Oxford: Oxford University Press, 2012), 1280b-1282a.

${ }^{28}$ Davis, One Virgin Too Many, 329.

${ }^{29}$ Davis, One Virgin Too Many, 224.

${ }^{30}$ The Pontifex Maximus was the chief priest of the College of Pontiffs (Collegium Pontificum). Traditionally, this Collegium consisted of the Pontifex Maximus and the other pontifices, the Rex Sacrorum (a senatorial priesthood), the fifteen flamines and the Vestals. Following Augustus' assumption of the title of Pontifex Maximus, the office gradually lost its traditional role as chief high priest and, under the Empire, became an aspect of imperial power. On the relationship of rituals and power in Imperial Rome, see Simon R. F. Price, Rituals and Power: The Roman Imperial Cult in Asia Minor, (Cambridge: Cambridge University Press, 1984).

${ }^{31}$ In contrast to the adventures of fictional detectives, actual detective work is ordinarily a more mundane pursuit in which the overwhelming majority of cases are solved by plea agreements. Currently, $94 \%$ of state criminal convictions and $97 \%$ of federal criminal convictions are the result of plea bargains (Emily Yoffe, "Innocence is Irrelevant," The Atlantic 320.2 (September 2017), 69. A similar estimate by the (fictional) Roman Cohortes Vigilum is that only "one case in fifty" is "complicated" (Davis, Ode to a Banker, (New York: Mysterious Press Books, 2001b), 57.
} 
picture of how a crime was committed, and by whom." 32 This comparison of the work of the historian with that of detectives was firmly established in 1969 with the publication of The Historian as Detective, edited by the historian Robin W. Winks, himself a connoisseur of detective novels. Like fictional detectives, the historian "either follows a chain of evidence to the suspect, or ... [he] begins with the suspect and, in retrograde fashion, follows the evidence back to the crime. ${ }^{33}$ It is unsurprising that the structures of historical narratives are shared by detective novels, ${ }^{34}$ since Poe's "tales of ratiocination" were introduced precisely during the time that "history" was itself being established and developed as an academic discipline separate from theology and literature. ${ }^{35}$ The "professional" reconstruction of a past event that is convincing to a historian, however, may prove less so to others, as is the case with detectives. The methodological problems require decisions about what evidence is relevant, about the relationship amongst the evidence, and a construction of a viable case from it. However, the kinds of evidence considered relevant may be reevaluated and judged irrelevant, or new evidence may be discovered; the appositeness of evidence adduced and the assumptions upon which the case was constructed may be questioned and an alternative scenario suggested. The "truth of the matter," for the historian, as for the detective, is determined intersubjectively by a "jury of their peers" as that which is "beyond reasonable doubt" — and even that "final" verdict is subject to appeal.

The fundamental issue to be considered concerns the nature of evidence. All possible evidential clues must be considered and, then, information that is irrelevant to the case must be extricated. One of the tropes of detective fiction is that significant evidential clues, while present in the narrative, are often overlooked by both the detective and the reader. Historians, too, often overlook or neglect significant evidence, especially as a result of their textocentric biases and their presumptive presuppositions of an underlying narrative by which texts are scripted.

Unlike the textual conceit of modern historians, our Roman detective Falco has no readily available library of significant texts at his disposal. Rather, most, if not all, of his evidence, like that available to modern detectives, is material and it is from this material evidence that detectives, fictive and actual, and some historians, must build their case. This neglect of an extensive range of evidence is especially characteristic of the textocentric historians of antiquity, and especially of historians of ancient religions, the evidence of material culture being abdicated to archaeologists. The various attempts to reconstruct a mythological narrative for the Roman cults of Mithras is a good example of the narratological bias. Despite historians' recognition that the primary characteristic of the religions of Western antiquity is imagery, for which the Roman cults of Mithras provide a principal example, ${ }^{36}$ historians

${ }^{32}$ Robin G. Collingwood, The Idea of History, (New York: Oxford University Press, [1946], 1956), 243.

${ }^{33}$ James Lee Burke, Creole Belle, (New York: Simon \& Schuster, 2012), 130.

${ }^{34}$ Dominick LaCapra, History and Criticism, (Ithaca, NY: Cornell University Press, 1985), 53.

${ }_{35}$ Arnaldo Momigliano, "The Introduction of the Teaching of History as an Academic Subject and Its Implications," Minerva 21.1 (1983), 13-15.

${ }^{36}$ Manfred Clauss, The Roman Cult of Mithras: The God and His Mysteries, trans. R. Gordon, (London: Routledge, 2001), 17. 
continue attempts to explain the plethora of imagistic evidence for these dispersed cults in terms of some presumed myth underlying their representations. While evidence from imagistic culture may be explained by some underlying narrative, it can often be explained otherwise, in terms of neurocognitive processes of vision, for example. ${ }^{37}$ Significantly, the view of early Christian life, fully documented from the evidence from material culture by Graydon Snyder, deviates in important ways from that of scholarly views based on the literary sources. ${ }^{38}$ For example, representations of the resurrection of Jesus and of the cross are absent from the evidence of material culture. This absence of representations of the cross and resurrection of Jesus, so central to Christian literary accounts, is especially striking since much of this evidence is from empyreal concerns documented from Christian catacombs. And while Biblical scholars, if asked, readily acknowledge Snyder's work, they rarely, if ever, cite it in theirs. It is partially for reasons of such evidential neglect that I have devoted much of my research on Hellenistic religions to considerations of historiographical methods that are as relevant to material as to textual evidence, specifically to the Roman cults of Mithras, for which the surviving evidence is almost entirely material. ${ }^{39}$

A second characteristic of historians, like that of fictive detectives, is a concern with "whodunit"? Consequently, detectives must interview everyone involved and trust no one. As literary critic Lisa Zunshine notes, everyone in detective novels could be lying, ${ }^{40}$ —and those investigated by Falco usually are. As Falco says in one instance, "It was thought that [those he is to investigate] were lying through their teeth-as they undoubtedly were, and so was everybody" ${ }^{41}$ — including, on occasion, the detective himself. ${ }^{42}$ Consequently fictional detectives as well as the "reader[s] of the detective story ... [are] supposed to 'suspect everybody"' 43 - a skeptical attitude characteristic of historians as well. ${ }^{44}$ And, if we know that one of the many suspects is the perpetrator but not know which one, "we had better have all of our attention focused on the problem at hand." ${ }^{45}$ If, after all, we are focused on "who committed the crime," then historiography like detective novels ultimately simulates our evolved abilities of survival.

${ }^{37}$ Luther H. Martin, "Seeing the Mithraic Tauroctony," in The Mysteries of Mithras and other Mystic Cults in the Roman World, ed. P. Johnston, A. Mastrocinque and László Takács, (Acta Antiqua Academiae Scientiarum Hungaricae. Budapest: Akadémiai Kiadó), forthcoming book.

38 The archaeological/material evidence for pre-Constantinian Christianity was compiled and published by Graydon F. Snyder, Ante Pacem: Archaeological Evidence of Church Life Before Constantine, (Macon GA: Mercer University Press, [1985], 2nd ed. 2003).

${ }^{39}$ Luther H. Martin, The Mind of Mithraists: Historical and Cognitive Studies of the Roman Cult of Mithras, (London: Bloomsbury, 2015).

${ }^{40}$ Lisa Zunshine, Why We Read Fiction: Theory of Mind and the Novel, (Columbus: The Ohio State University Press, 2006), 133.

${ }^{41}$ Davis, Two for the Lions, (New York: Mysterious Press, 1998), 5.

${ }^{42}$ Davis, Two for the Lions, 66.

${ }^{43}$ Zunshine, Why We Read Fiction, 5, 124, 130.

${ }^{44}$ Richard H. Popkin, "Scepticism and the Study of History," in Physics, Logic, and History, ed. W. Yourgrau and A. D. Breck, (Boston: Springer, 1970), 209-230.

${ }^{45}$ Zunshine, Why We Read Fiction, 146, emphasis original. 
Zunshine argues that the consideration of each and every possibility by detectives, by historians, and even by the readers of detective novels, can result in cognitive overload. "Monitoring and reestablishing the boundaries for truth," which is crucial to our survival and "doing it again and again on the same material" invokes "a constant delicate interplay between [the] energy costs and benefits" of our brains. ${ }^{46}$ The repetitive overloads that are encountered by the "attention-focusing and information-processing systems" of our "representation-hungry brain-mind" produce experimental possibilities, which, Zunshine concludes, are what literary stories and historical narratives both explore. ${ }^{47}$

Because of the aggregate weight of their evolutionary history, stories have come to feel pleasurable in new, hitherto-unexpected, ways—especially detective stories. ${ }^{48}$ Just hearing stories releases oxytocin, a neuropeptide which stimulates prosocial behaviors and feelings of well-being. ${ }^{49}$ An initial neglect of significant evidence and its enjoyable "discovery" contributes to a pleasingly satisfactory conclusion, a literary conceit that is, however, unavailable to the historian who must deal with the actual "facts of the matter."

\section{The Historian as Scientific Detective}

Even as the detective genre of literature developed at a time during which history was being established as an academic discipline, the Darwinian revolution was, at the same time, transforming biology and enlivening scientific interests generally. Whereas war had been the theme of fictional and historical texts in the West from Gilgamesh and the Iliad to War and Peace, ${ }^{50}$ detective novels emerged as "the distinctive literary genre of modern, industrial societies. ${ }^{51}$ They currently account for between 25 and 40 percent of all fiction book sales in the western world, ${ }^{52}$ and are the bestselling genre of fiction in the United States ${ }^{53}$ and the UK. ${ }^{54}$

${ }^{46}$ Brains are expensive devices that consume "sixteen times as much energy per unit weight" than does muscle tissue (Zunshine, Why We Read Fiction, 70).

${ }^{47}$ Zunshine, Why We Read Fiction, 148.

${ }^{48}$ Zunshine, Why We Read Fiction, 148-149.

${ }^{49}$ Alex Rosenberg, How History Gets Things Wrong: The Neuroscience of Our Addiction to Stories, (Cambridge MA: The MIT Press, 2018), 86; Paul J. Zak, "Why Inspiring Stories Make Us React: The Neuroscience of Narrative," Cerebrum: The Dana Forum on Brain Science (National Institutes of Health), 2015: 2.

${ }^{50}$ Arnaud Blin, War and Religion: Europe and the Mediterranean from the First through the Twenty-First Centuries, (Oakland: University of California Press, 2019).

${ }^{51}$ Christopher Badcock, “The Genius of Detective Fiction.” 2010. https://www.psychologytoday.com/us/blog/ the-imprinted-brain/201001/the-genius-detective-fiction (accessed 2/27/2019).

52 Beemgee, "Why is Crime Fiction so Popular? https://www.beemgee.com/blog/crime-fiction/ (blog: accessed 4/27/2019).

53 "Publishing ... and Other Forms of Insanity," November 16, 2017. https://publishedtodeath. blogspot. com/2017/11/what-are-most-popular-literary-genres.html (accessed 5/2/2019).

${ }^{54}$ Sophie Hannah, "It's No Mystery that Crime is the Biggest-selling Genre in Books," The Guardian: Books Blog, Crime Fiction, 12 April 2018. https://www.theguardian.com/books/booksblog/2018/apr/12/mysterycrime-fiction-bestselling-book-genre-sophie-hannah (accessed 6/22/2019). 
In contrast to Falco's first-century methods of tedious legwork, extensive and wideranging interrogations, and logical deduction, modern investigations by fictional detectives have been dramatically influenced by forensic science, the application of scientific methods to criminal investigations. It is as if Sherlock Holmes has joined the cast of CSI, the toprated American TV show about contemporary "crime scene investigators." This series has popularized scientifically-based investigative techniques, whereby cases are (purportedly) solved with alacrity, cold cases put to rest, and even formerly unsuccessfully appealed verdicts overturned. ${ }^{55}$ Modern developments of forensic science have been correlated by some with the growing popularity of detective novels. ${ }^{56}$ The question is whether a scientific approach to the solution of fictive past crimes might also be applicable to historiographical research.

Yale historian John Lewis Gaddis has argued that historians, like detectives, "start with surviving structures, whether they are archives, artifacts, or even memories. They then deduce the processes that produced them... allow[ing] for the fact that most sources from the past don't survive, and that most daily events don't even generate a survivable record in the first place. ${ }^{57}$ Rejecting the oxymoronic relativism of postmodernism,,${ }^{58}$ Gaddis argues that historiographical research must at least "approach the standards for verification that exist within the social, physical, and biological sciences." 59

Social scientists, at least since Marx, have proposed "testable" theories for historical research. ${ }^{60}$ The question then, of course, is the extent to which "it is possible...to apply propositions developed in one time and place to other eras and cultures." ${ }^{61}$ Rather than a social-scientific model for historiography, German sociologist and philosopher of history Georg Simmel declared "the material of history" to be "the cognitive functions of the mind." ${ }^{62}$ The development of the cognitive sciences during the latter part of the twentieth century makes viable a cognitive historiographical approach to Simmel's identification of the "material of history." The methodological appeal of cognitive models is that they go

\footnotetext{
${ }^{55}$ Note 31 supra.

${ }^{56}$ Ronald R. Thomas, Detective Fiction and the Rise of Forensic Science, (Cambridge: Cambridge University Press, 1999).

${ }^{57}$ John Lewis Gaddis, The Landscape of History: How Historians Map the Past, (Oxford: Oxford University Press, 2002), 41.

${ }^{58}$ Gaddis, The Landscape of History, 9-10, 142-143.

${ }^{59}$ Gaddis, The Landscape of History, 17. On the abuses of science by postmodernists, see Alan Sokal and Jean Bricmont, Fashionable Nonsense: Postmodern Intellectuals' Abuse of Science, (New York: Picador, 1998).

${ }^{60}$ Rodney Stark, The Rise of Christianity: A Sociologist Reconsiders History, (Princeton: Princeton University Press, 1996), 23.

${ }^{61}$ Stark, The Rise of Christianity, 21-22; Ronald F. Hock, (unpublished paper), "Response to Rodney Stark's Jewish Conversion and the Rise of Christianity", presented at the Social History of Early Christianity Group of the Society of Biblical Literature, Atlanta, 1986, cited by Stark, The Rise of Christianity, 21-22; see also Russell T. McCutcheon, Willi Braun, Burton Mack, and Randall Collins, "A Symposium on Rodney Stark's The Rise of Christianity," Religious Studies Review 25 (1999), 127-139; and Wayne A. Meeks, The First Urban Christians: The Social World of the Apostle Paul, (New Haven: Yale University Press, 1983), 20.

${ }^{62}$ Georg Simmel, Die Probleme der Geschichtsphilosophie, (Leipzig: Duncker \& Humblot, 1892); The Problems of the Philosophy of History: An Epistemological Essay, trans. of 2nd enlarged ed. (1905) by Guy Oakes, (New York: Free Press, 1977), vii, 39, 43.
} 
behind the familiar metaphors, typologies, or sets of concepts proposed on the basis of modern historiographical assumptions to offer explanations for historical formations that are grounded in universal features of human cognition, and that are testable. ${ }^{63}$

In addition, a group of historians began, in the 1990s, to acknowledge a related "return to [evolutionary] science" in their historiography by incorporating the study of prehistory and protohistory, generally relegated to archaeologists and anthropologists, into an extended view of "deep history." Deep historiography incorporates into traditional historiographical methods questions about how the evolved biocognitive substrate of Homo sapiens might inform historical evidence and change, from the evolutionary emergence of the species to the present. ${ }^{64}$

Scientific historiography, like the scientific detection depicted in modern mystery novels shares, at base, a process of accumulating data possibly relevant to the problem addressed, of systematically eliminating false possibilities from that data, and constructing the most probable conclusion based on a cause-and-effect relationship of that data, ${ }^{65}$ a process of detection already exemplified in the first-century delations of Falco. Subsequently, scientific historiographies, like contemporary criminal investigations, came to employ modern scientific methods, such as statistical analyses of quantifiable evidence (where sufficient evidence might survive from the past), ${ }^{66}$ contemporary network theory, computational modeling such as multi-agent simulations to assess historiographical theorizing, compensating for evidential biases identified by behavior economists, etc. ${ }^{67}$ And, there are more recent contributions to the study of ancient history from the scientific areas of climate, archaeobotany, zooarchaeology, DNA studies, etc. ${ }^{68}$ However, since historiographies—like criminal detection-may arrive at alternative accounts for the same events, those based

${ }^{63}$ A new Journal of Cognitive Historiography has now formalized that appeal. See also Luther H. Martin, "Rituals, Modes, Memory and Historiography: The Cognitive Promise of Harvey Whitehouse," Journal of Ritual Studies 16. 2 (2002), 31; see Harvey Whitehouse, Inside the Cult: Religious Innovation and Transmission in Papua New Guinea, (Oxford: Oxford University Press, 1995); Whitehouse, Arguments and Icons: Divergent Modes of Religiosity, (Oxford University Press, 2000); and Stark, The Rise of Christianity, 25-26.

${ }^{64}$ Matthew H. and Doris V. Nitecki, eds., History and Evolution, (Albany: SUNY, 1992); David Gary Shaw and Philip Pomper, eds., The Return of Science: Evolutionary Ideas and History, Theme Issue of History and Theory 38.4 (1999); Shaw, ed., Agency after Postmodernism, Theme Issue of History and Theory 40.4 (2001); Daniel Lord Smail, On Deep History and the Brain, (Berkeley: University of California Press 2008); Andrew Shryock and D. L. Smail, eds., Deep History: The Architecture of Past and Present, (Berkeley: University of California Press, 2011); and Luther H. Martin, “The Deep History of Religious Ritual,” in Secular Theory, Deep History: Scientific Studies of Religion, Collected Essays of Luther H. Martin, (Berlin: de Gruyter, 2014), 254-271.

${ }^{65}$ Joseph Agassi, “The Detective Novel and Scientific Method," Poetics Today 3.1 (1982), 99-108.

${ }^{66}$ E. g., Edward Slingerland, Ryan Nichols, Kristoffer Neilbo, Carson Logan. "The Distant Reading of Religious Texts: A "Big Data" Approach to Mind-Body Concepts in Early China." Journal of the American Academy of Religion 85. 4 (2017): 985-1016.

${ }^{67}$ Luther H. Martin, "Is There a Future for a Scientific Study of Religion?" Presentation to a conference on Step Back and Look Beyond: Studying Religion after 2020, Bochum, Germany, March 11-13, 2020.

${ }^{68}$ Walter Scheidel, editor. The Science of Roman History: Biology, Climate, and the Future of the Past. Princeton: Princeton University Press, 2018. I am indebted to an anonymous reviewer of this article for encouraging me to further emphasize the employment of actual scientific methods employed by contemporary historians. 
upon empirical evidence and testable scientific hypotheses may be judged to be a more plausible reconstruction of the facts of the matter.

\section{Historical Narratives and Detective Stories}

In 1973, Hayden White disturbed the staid academy of historians with his innovative analysis of historical narratives as literature. Although White argued that history is an agreed upon fiction (borrowing the characterization attributed to Napoleon) ${ }^{69}$ that relies on narrative for meaning, ${ }^{70}$ he did not mean that what historians since Hegel have termed the "res gestae," the actual "things said and done" in the past, ${ }^{71}$ could be denied or was not "true". As historian Eric Hobsbawm has sagely concluded, "Either Elvis Presley is dead or he isn't." 72

Most recently, the philosopher Alex Rosenberg has argued that historical narratives are not only subjective and interested, but he surpasses White's point by asserting that they are simply false, no truer than literary stories. ${ }^{73}$ The "way of thinking" that accounts for historical as for fictive narratives, Rosenberg argues, is based on "Theory of Mind" (ToM). ToM is a neurocognitive reference to folk-psychological understandings of the mental states of others, and of one's own, with its associated inferences of agency, intentionality, and teleology. It is an evolved and "hardwired" characteristic of human cognition, ${ }^{74}$ which had proved adaptive for small-scale hunter-gather societies prior to the Holocene. ${ }^{75}$ In a markedly foreshortened synopsis of cognitive evolution, Rosenberg asserts that ToM is required for language, stories followed language, and, then, there was "only a few short steps" to a "fixation on stories."76 This "fixation on stories," Rosenberg argues, inexorably transforms historical chronologies into "meaningful" narratives" that explain "what happened in terms of the motives and the perspectives of human agents whose choices, decisions, and actions made those events happen." ${ }^{\prime 8}$ This intuitive preference for agentic stories over analytical

\footnotetext{
${ }^{69}$ Anthony K. Jensen, "Nietzsche and the Truth of History," in The New Cambridge Companion to Nietzsche, ed. Tom Stern, (Cambridge: Cambridge University Press, 2019), 249-272.

${ }^{70}$ Hayden White, "Interpretation in History," New Literary History 4.2 (1973), 281-314.

${ }^{71}$ G. W. F. Hegel, Vorlesung über die Philosophie der Weltgeschichte, (Berlin: Verlag von Duncker und Humblot, 1837), The Philosophy of World History, trans. J. Sibree, (New York: Dover, [1857] 1956), 60.

72 Eric Hobsbawm, "The New Threat to History," The New York Review of Books, (16 December 1993), 62-64: 63.

${ }^{73}$ Rosenberg, How History Gets Things Wrong, 215, 249.

${ }^{74}$ Rosenberg, How History Gets Things Wrong, 73; Alison Gopnik, "Theory of Mind," in The MIT Encyclopedia of the Cognitive Sciences, eds. Robert A. Wilson and Frank C. Keil, (Cambridge MA: The MIT Press, 1999), 838-840; Winks, The Historian as Detective, xvi.

${ }^{75}$ Rosenberg, How History Gets Things Wrong, 41.

${ }^{76}$ Rosenberg, How History Gets Things Wrong, 70.

77 Rosenberg, How History Gets Things Wrong, 87.

${ }^{78}$ Rosenberg, How History Gets Things Wrong, 2.
} 
modes of thinking ${ }^{79}$ echoes the "great man" view of history popularized by Thomas Carlyle in $1841 .{ }^{80}$ Carlyle's agentocentric view of history has been challenged by social scientists since Herbert Spencer, ${ }^{81}$ who argue, instead, for a social history that emphasizes structure over agency. Rosenberg's own criticism is that narratives which explain and understand history in terms of the actions of individual agents rely upon ToM and, as such, are little more than fiction. ${ }^{82}$

With reference to detective novels, ToM is largely a concern with the nature of criminal minds (a concern adroitly portrayed by Davis in a discussion between Falco and his wife/ partner Helena, ${ }^{83}$ and with the corresponding mental state of the investigating detective. A summary of Falco's current case by Helena ${ }^{84}$ nicely mirrors the recent technique of psychological profiling developed and widely used by the FBI during the final third of the last century. This modern technique, however, is less forensic science than it is a folkpsychological construction of ToM-based intuitions. ${ }^{85}$

Like Rosenberg, Zunshine also recognizes that ToM is central to and common to both literary stories and historical narratives ${ }^{86}$ Unlike Rosenberg, however, she argues there is a significant difference between the two genres. Literature, according to Zunshine, can be viewed as experiments in "mental states potentially available to us but at a given moment differing from our own." ${ }^{87}$ By creating narrative frameworks of mental potentialities, our ToM experiments with certain aspects of our "metarepresentational" ability. ${ }^{88}$ By "metarepresentation," Zunshine refers to our second-order cognitive ability for keeping "track of sources of our representations." ${ }^{99}$ By "source," historians generally refer to any "material that is [causal of or] contemporary with the events being examined." ${ }^{00}$ According to Zunshine, sources are "metarepresented" by assimilating them with existing knowledge

\footnotetext{
${ }^{79}$ Rosenberg, How History Gets Things Wrong, 61-62, 87. Since the Pleistocene, humans have sought agentic explanations for almost all natural processes in the desires and beliefs of an all-powerful deity to which ToM is applied, in supplication, propitiation, exculpation, and celebration (Rosenberg, How History Gets Things Wrong, 185). Agency is replaced by natural causes in scientific explanations.

${ }^{80}$ Thomas Carlyle, On Heroes, Hero-Worship and the Heroic in History, (London: James Fraser, 1841, 1993).

${ }^{81}$ Herbert Spencer, The Study of Sociology, (New York: Appleton 1896).

${ }^{82}$ Rosenberg, How History Gets Things Wrong, passim, esp. 175, 177, 201, 245.

${ }^{83}$ Davis, Three Hands in the Fountain, New York: Mysterious Press, 1996), 136-138.

${ }^{84}$ Davis, Three Hands in the Fountain, 177-178.

${ }^{85}$ Christopher Devery, "Criminal Profiling and Criminal Investigation," Journal of Contemporary Criminal Justice 26.4 (2010), 393-409.

${ }^{86}$ Zunshine, Why We Read Fiction, 133.

${ }^{87}$ Zunshine, Why We Read Fiction, 17, emphasis original.

${ }^{88}$ Zunshine, Why We Read Fiction, 133.

${ }^{89}$ Zunshine, Why We Read Fiction 47. Zunshine employs the concept of "metarepresentation" with reference to Dan Sperber's et al. usage in Sperber, ed., Metarepresentations: A Multidisciplinary Perspective, (New York: Oxford University Press, 2000), (Zunshine, Why We Read Fiction, 48).

${ }^{90}$ Winks, The Historian as Detective, $\mathrm{xx}$.
} 
inferences ${ }^{91}$ and storing them "under advisement." ${ }^{92}$ Especially with detective stories, ${ }^{93}$ one is "encouraged by the laws of the genre to store nearly every attribution of the mental state behind each character's behavior with a very 'strong' metarepresentational tag." 94 Metarepresentation, then, "provides a temporarily useful explanation of the states of mind behind the suspicious behavior ... [of fictive criminal suspects, for example, that] can be adjusted, confirmed, or discarded...once more information comes in." 95

Reminiscent of Spencer's emphasis on social history, detective stories, like literature generally, can be viewed as simulations of the social world, ${ }^{96}$ as Davis' Falco series lucidly illustrate for the first-century Roman empire. Such simulations have ancient adaptive roots. The demands of a hunter-gatherer lifestyle eventually required that groups pay attention to the world around them, and maintain a vast knowledge concerning the local and extended environments, including the ability to predict seasonal changes and understand their effects on plants and animals throughout the year. Such spatial and temporal knowledge was communicated in stories told 'round the campfire. Fiction, then, helps us understand how imagination works to create possible worlds, and how mental models are formed of others and ourselves Historical narratives, Zunshine argues, like literature, are also simulations of the social world; however they are characterized by much weaker metarepresentational tagging than fiction, ${ }^{97}$ since metarepresentations in historical narrative are constrained by evidence; the greater the evidence, the fewer metarepresentations. Taken to its logical conclusion, a diminution of metarepresentational framing from historical narratives means removing the historian (and his/her ToM) from the narrative. "The ultimate goal" of historians, Zunshine argues, is to have the information they provide be stored "simply as 'X,' and not as 'Thucydides says that ' $\mathrm{X}$ '."

If the historical record is "anything more than a chronology," Rosenberg concludes, it is simply wrong because historical narratives introduce human "meanings" — social, political, religious ${ }^{99}$ - that are unverifiable. ${ }^{100}$ "Academic histories," on the other hand, are influenced by social, behavioral, and natural sciences, especially the neurosciences. Even as Newton excluded purpose from folk-physics, ${ }^{101}$ and Darwin excluded the appearance of design from folk- biology, ${ }^{102}$ the neurosciences, Rosenberg argues, are now demythologizing the

\footnotetext{
${ }^{91}$ Zunshine, Why We Read Fiction, 49.

${ }^{92}$ Zunshine, Why We Read Fiction, 50.

${ }_{93}$ Zunshine, Why We Read Fiction, 133.

${ }_{94}$ Zunshine, Why We Read Fiction, 129.

${ }^{95}$ Zunshine, Why We Read Fiction, 128.

${ }^{96}$ Keith Otaley, "Fiction: Simulation of Social Worlds." Trends in Cognitive Science, 20.8 (2016), 618-629.

${ }^{97}$ Zunshine, Why We Read Fiction, 70.

${ }^{98}$ Zunshine, Why We Read Fiction, 71; also Winks, The Historian as Detective, xiv.

${ }^{99}$ Rosenberg, Why History Gets Things Wrong, 45, 160, 248. In one of Davis' novels, Falco encounters a historian who, as Rosenberg commends, is concerned only with "cataloguing events" (Davis, Ode to a Banker, 131), an approach to history that Falco, at least, "would never allow himself to read" (133).

${ }^{100}$ Rosenberg, Why History Gets Things Wrong, 247.

${ }^{101}$ Rosenberg, Why History Gets Things Wrong, 84.

${ }^{102}$ Rosenberg, Why History Gets Things Wrong, 85.
} 
folk-psychological effects of ToM. ${ }^{103}$ A neuroscientific exposé of how ToM latches onto and misrepresents history through narrative ${ }^{104}$ is the only way, Rosenberg concludes, to vindicate narrative history's recourse to ToM. ${ }^{105}$

While historians must strive to attenuate ToM in their inevitable narrativizing, it is surely relevant to emphasize that the "facts" of the historical evidence have themselves been shaped by the ToM bias and should be interpreted as such. This is especially the case with the textual evidence upon which historians principally draw. And, to the extent that historical texts are fictive narratives as a consequence of the ToM bias, they cannot be viewed as preserving accurate historical evidence.

Physicists Alan Sokal and Jean Bricmont have counseled that, "if one does not ... take into account the empirical aspects,"- the "facts of the matter" [i.e., the chronologies] - then scientific [and historical] discourse indeed becomes nothing more than a 'myth' or 'narration'." 106 On the other hand, these prominent physicists conclude that: "It is perfectly legitimate to turn to ... literature in order to obtain some kind of nonscientific understanding of those aspects of human experience that cannot, at least at present, be tackled more rigorously." 107

\section{Conclusion}

So ..., until "those aspects of human experience that cannot... be tackled more rigorously" have been elucidated by science- the pursuit of which has, itself, inspired poetic awe from Darwin to Dawkins, ${ }^{108}$ - I shall continue to read literature, not only for my leisurely enjoyment but for the insights it offers into those aspects of the human condition otherwise unmapped. Especially unlikely is any unrealistic expectation that advances in science will ever be able fully to "fill-in-the-gaps" of the incomplete historical record. Consequently, a scientific historiography will always entail, to a greater or lesser extent, the informed imagination of the historian to "connect the dots" of historical remains but, hopefully, a theoretically substantiated and empirically informed imagination. And, as a historian, I shall continue to read detective stories, for as Robin Collingwood and Robin Winks have emphasized, and as James Lee Burke has epigraphed above, the work of historians is that of detectives. As a historian of Graeco-Roman religions, I, of course, especially appreciate the Falco novels by Lindsey Davis and her lively descriptions of the socio-political machinations in first-century Rome, within which Falco's delations are inevitably entwined, as well her

\footnotetext{
${ }^{103}$ Rosenberg, Why History Gets Things Wrong, 186.

${ }^{104}$ Rosenberg, Why History Gets Things Wrong, 110.

${ }^{105}$ Rosenberg, Why History Gets Things Wrong, 114.

${ }^{106}$ Sokal and Bricmont. Fashionable Nonsense, 97.

${ }^{107}$ Sokal and Bricmont, Fashionable Nonsense, 188.

${ }^{108}$ Charles Darwin, The Origin of Species, (New York: Signet Classic, [1859], 2003), 458; Richard Dawkins, Unweaving the Rainbow: Science, Delusion, and the Appetite for Wonder, (Boston: Houghton Mifflin, 1998), $\mathrm{x}, 15-18,27$.
} 
vivid descriptions of everyday life in the capital and its provinces, to which the informer's adventures lead. While such details are mostly absent from historical chronicles, and are imaginative constructions inexorably shaped by Theory of Mind, they are, nevertheless, as accurate as a historiography can be given the partial testimonies about those "things said and done" in the past. And, detective stories, such as the Falco series, are as historically instructive as they are pleasurable to read.

\section{Bibliography}

Agassi, Joseph. “The Detective Novel and Scientific Method.” Poetics Today 3.1 (1982.): 99-108.

Alter Alexandra. “The (Really) Long Goodbye: He`s Got a Gun, a Badge—and Rheumatoid Arthritis; The Iconic Detectives of Best-selling Authors from Michael Connelly to Ruth Rendell are Fighting a New Foe: Old Age.” Wall Street Journal (Eastern edn.). July 1 (2011): D.1.

Badcock, Christopher. “The Genius of Detective Fiction,” 2010. Accessed 2/27/2019. https://www.psychologytoday.com/us/blog/the-imprinted-brain/201001/the-genius-detective-fiction.

Becker, Carl L. "Everyman His Own Historian." American Historical Review 37 (1932): 221-236; reprinted in The Historian as Detective: Essays on Evidence, edited by R. W. Winks. New York: Harper and Row, 1969, 5-23.

Beemgee. "Why is Crime Fiction so Popular? Accessed 4/27/2019. https://www.beemgee.com/blog/crimefiction/ (blog).

Blin, Arnaud. War and Religion: Europe and the Mediterranean from the First through the Twenty-First Centuries. Oakland: University of California Press, 2019.

Burke, James Lee. Creole Belle. New York: Simon \& Schuster, 2012.

Carlyle, Thomas. On Heroes, Hero-Worship and the Heroic in History. London: James Fraser, [1841] 1993.

Carroll, Maureen. 2006. Spirits of the Dead: Roman Funerary Commemoration in Western Europe. Oxford: Oxford University Press.

Clauss, Manfred. The Roman Cult of Mithras: The God and His Mysteries, translated by R. Gordon. London: Routledge, 2001.

Collingwood, Robin G. The Idea of History. New York: Oxford University Press, [1946] 1956.

Darwin, Charles. The Origin of Species. New York: Signet Classic, [1859] 2003.

Davis, Lindsey. The Iron Hand of Mars. London: Hutchinson, 1992.

Davis, Lindsey. Three Hands in the Fountain. New York: Mysterious Press, 1996.

Davis, Lindsey. Two for the Lions. New York: Mysterious Press, 1998.

Davis, Lindsey. One Virgin Too Many. New York: Mysterious Press, 1999.

Davis, Lindsey. Falco on the Loose [Three of Davis' novels bound as one: Last Act in Palmyra (1994), Time to Depart (1995), A Dying Light in Corduba (1996)]. London: Arrow Books, 2001a.

Davis, Lindsey. Ode to a Banker, New York: Mysterious Press Books, $2001 \mathrm{~b}$.

Davis, Lindsey. “Authors' Introduction,” The Silver Pigs, New York: Minotaur Books [1989], 2011. 
Dawkins, Richard. Unweaving the Rainbow: Science, Delusion, and the Appetite for Wonder. Boston: Houghton Mifflin, 1998.

Devery, Christopher. "Criminal Profiling and Criminal Investigation." Journal of Contemporary Criminal Justice 26.4 (2010): 393-409.

Dickerson, Mary Jane. "The Convergence of History and Poetry: Part I-Toward a Poetics of the Past," in Vermont Poets and Their Craft, edited by Neil Sheppart and Tamra J. Higgens, Brattleboro, Vermont: Green Writer's Press, 2019, 83-92.

Gaddis, John Lewis. The Landscape of History: How Historians Map the Past. Oxford: Oxford University Press, 2002.

Graf, Fritz. "ritual," The Oxford Classical Dictionary. Fourth ed. edited by Simon Hornblower, Anthony Spawforth., and Esther Eidenow. 1280b-1282a. Oxford: Oxford University Press, 2012.

Gopnik, Alison. "Theory of Mind," in The MIT Encyclopedia of the Cognitive Sciences, edited by Robert A. Wilson and Frank C. Keil,. Cambridge MA: The MIT Press, 1999, 838-840.

Hannah, Sophie. "It's No Mystery that Crime is the Biggest-selling Genre in Books." The Guardian: Books Blog, Crime Fiction, 12 April 2018. Accessed 6/20/2019. https://theguardian.com/books/booksblog/2018/ apr/12/mystery-crime-fiction-bestselling-book-genre-sophie-hannah

Hegel, G. W. F. The Philosophy of History, translated by J. Sibree. New York: Dover, [1861] 1956.

Hersch, Karen K. The Roman Wedding: Ritual and Meaning. Cambridge: Cambridge University Press, 2010. Hobsbawm, Eric. "The New Threat to History." The New York Review of Books, 16 December 1993, 62-64.

Hock, Ronald F. "Response to Rodney Stark's 'Jewish Conversion and the Rise of Christianity', paper presented at the Social History of Early Christianity Group of the Society of Biblical Literature, Atlanta, 1986, unpublished, cited by Stark 1996: 21-22.

Jensen, Anthony K. "Nietzsche and the Truth of History," in The New Cambridge Companion to Nietzsche, edited by Tom Stern, Cambridge: Cambridge University Press, 2019, 249-272.

Kismaric, Carole and Marvin Heiferman. The Mysterious Case of Nancy Drew \& The Hardy Boys. New York: Simon \& Schuster, 1998.

LaCapra, Dominick. History and Criticism. Ithaca, NY: Cornell University Press, 1985.

Martin, Luther H. "Rituals, Modes, Memory and Historiography: The Cognitive Promise of Harvey Whitehouse". Journal of Ritual Studies 16. 2 (2002): 30-33.

Martin, Luther H. "The Deep History of Religious Ritual," in Secular Theory, Deep History: Scientific Studies of Religion, Collected Essays of Luther H. Martin, Berlin: de Gruyter, 2014, 254-271

Martin, Luther H. The Mind of Mithraists: Historical and Cognitive Studies of the Roman Cult of Mithras. London: Bloomsbury, 2015.

Martin, Luther H. "Consilience: Science, the Humanities, and the Study of Religion." Culture and Research, forthcoming article.

Martin, Luther H. "Seeing the Mithraic Tauroctony," in The Mysteries of Mithras and other Mystic Cults in the Roman World, edited by P. Johnston, A. Mastrocinque and László Takács, Acta Antiqua Academiae Scientiarum Hungaricae. Budapest: Akadémiai Kiadó, forthcoming book.

Martin, Luther H. "Is There a Future for a Scientific Study of Religion?” Presentation to a conference on Step Back and Look Beyond: Studying Religion after 2020, Bochum, Germany, March 11-13, 2020. 
McCutcheon, Russell T., Willi Braun, Burton Mack, and Randall Collins, "A Symposium on Rodney Stark’s The Rise of Christianity. Religious Studies Review 25 (1999): 127-139.

Meeks, Wayne A. The First Urban Christians: The Social World of the Apostle Paul. New Haven: Yale University Press, 1983.

Momigliano, Arnaldo. "The Introduction of the Teaching of History as an Academic Subject and Its Implications.” Minerva 21.1 (1983): 1-15.

Mynott, Jeremy. Birds in the Ancient World Oxford: Oxford University Press, 2018.

New World Encyclopedia: “Poe.” Accessed 5/2/2019 http://www.newworldencyclopedia.org/entry/ Edgar_Allan_Poe

Nitecki, Matthew H. and Doris V. Nitecki, eds. History and Evolution. Albany: SUNY, 1992.

Otaley, Keith. "Fiction: Simulation of Social Worlds." Trends in Cognitive Science, 20.8 (2016): 618-629.

Pachis, Panayotis and Donald Wiebe. "Preface," Chasing Down Religion: In the Sights of History and the Cognitive Sciences. Essays in Honor of Luther H. Martin, edited by P. Pachis and D. Wiebe, Thessaloniki: Barbounakis Publications, 2010, XLVII-XLIX; rpt. by Equinox: Sheffield, UK, 2010, XXXVI-XXXVIII.

Popkin Richard H. "Scepticism and the Study of History," in Physics, Logic, and History, edited by W. Yourgrau and A. D. Breck, Boston: Springer, 1970, 209-230.

Price, Simon R. F. Rituals and Power: The Roman Imperial Cult in Asia Minor. Cambridge: Cambridge University Press, 1984.

"Publishing ... and Other Forms of Insanity," November 16, 2017. Accessed 5/2/2019. https://publishedtodeath.blogspot.com/2017/11/what-are-most-popular-literary-genres.html

Rosenberg, Alex. How History Gets Things Wrong: The Neuroscience of Our Addiction to Stories. Cambridge MA: The MIT Press, 2018.

Rutledge, Steven. H. Imperial Inquisitions: Prosecutors and Informants from Tiberius to Domitian. London: Routledge, 2001.

Scheidel, Walter ed. The Science of Roman History: Biology, Climate, and the Future of the Past. Princeton: Princeton University Press, 2018.

Shaw, David Gary, ed. Agency after Postmodernism. Theme Issue of History and Theory 40.4 (2001).

Shaw, David Gary and Philip Pomper, eds. The Return of Science: Evolutionary Ideas and History. Theme Issue of History and Theory 38.4 (1999).

Shryock, Andrew and Daniel Lord Smail. Deep History: The Architecture of Past and Present. Berkeley: University of California Press, 2011.

Slingerland, Edward, Ryan Nichols, Kristoffer Neilbo, Carson Logan. 2017. "The Distant Reading of Religious Texts: A "Big Data" Approach to Mind-Body Concepts in Early China." Journal of the American Academy of Religion 85. 4: 985-1016.

Smail, Daniel Lord. On Deep History and the Brain. Berkeley: University of California Press, 2008.

Silverman, Kenneth. Edgar A. Poe: Mournful and Never-ending Remembrance. New York: Harper Perennial, 1991.

Simmel, Georg. The Problems of the Philosophy of History: An Epistemological Essay, trans. of 2nd ed., by Guy Oakes. New York: Free Press, [1905] 1977. 
Snyder, Graydon F. Ante Pacem: Archaeological Evidence of Church Life Before Constantine. Macon GA: Mercer University Press., [1985] 2003.

Sokal, Alan and Jean Bricmont. Fashionable Nonsense: Postmodern Intellectuals' Abuse of Science. New York: Picador, 1998.

Sperber, Dan, ed. Metarepresentations: A Multidisciplinary Perspective. New York: Oxford University Press, 2000. Spencer, Herbert. The Study of Sociology. New York: Appleton,1896.

Stark, Rodney. The Rise of Christianity: A Sociologist Reconsiders History. Princeton: Princeton University Press. 1996.

Thomas, Ronald R. Detective Fiction and the Rise of Forensic Science. Cambridge: Cambridge University Press, 1999.

White, Hayden. Metahistory: The Historical Imagination in Nineteenth-century Europe. Baltimore: Johns Hopkins University Press, 1973.

White, Hayden. "Interpretation in History." New Literary History 4.2 (1973): 281-314.

Whitehouse, Harvey. Inside the Cult: Religious Innovation and Transmission in Papua New Guinea. Oxford: Oxford University Press, 1995.

Whitehouse, Harvey. Arguments and Icons: Divergent Modes of Religiosity. Oxford University Press, 2000.

Williams, Wirt. Review of James Lee Burke, Half of Paradise, "On the Tracks to Doom: HALF OF PARADISE” (Boston: Houghton Mifflin). New York Times Book Review, 14 March 1965: BR46

Winks, Robin W. The Historian as Detective: Essays on Evidence. New York: Harper \& Row, 1969.

Yoffe, Emily. "Innocence is Irrelevant.” The Atlantic, 320.2 (September 2017): 66-74.

Zak, Paul J. "Why Inspiring Stories Make Us React: The Neuroscience of Narrative." Cerebrum: The Dana Forum on Brain Science 2015: 2.

Zunshine, Lisa. Why We Read Fiction: Theory of Mind and the Novel. Columbus: The Ohio State University Press, 2006. 